\title{
Analisis Pengaruh Karakteristik Perusahaan Terhadap Pengungkapan Tanggung Jawab Sosial Perusahaan dalam Laporan Tahunan Perusahaan Manufaktur yang Terdaftar di BEI Periode 2009-2010
}

\author{
Erna Hidayah" \\ Windi Pamungkas**
}

\begin{abstract}
This study aimed to analyze the effect of firm characteristics on the disclosure of corporate social responsibility. The characteristics are proxied by the management ownership, leverage, size of the company and the profitability. While the disclosure of corporate social responsibility is proxied by CSR Index. The samples of this research were 48 manufacturing companies. Based on the hypothesis test, it was found that ownership management and profitability did not significantly affect the disclosure of corporate social. responsibility while leverage variable and firm size significantly affected the disclosure of corporate social responsibility.
\end{abstract}

Keywords : The disclosure of corporate social responsibility, management ownership, leverage, size and profitability

\section{Pendahuluan}

Dampak lingkungan merupakan salah satu hal yang menjadi perhatian masyarakat dan perusahaan saat ini. Perusahaan mempunyai peran, selain memberi manfaat positif terhadap ekonomi juga berkontribusi terhadap menurunnya kondisi lingkungan dan sosial masyarakat. Manfaat positif tersebut diantaranya yaitu perusahaan memproduksi barang dan jasa sehingga menyerap tenaga kerja, sehingga memberikan dampak terhadap kemajuan ekonomi. Disisi lain aktivitas perusahaan tersebut juga tidak dapat dipungkiri akan memberikan dampak terhadap lingkungan sosial seperti polusi udara, limbah, keselamatan tenaga kerja dan lain sebagainya.

Di dalam akuntansi konvensional, pusat perhatian perusahaan hanya terbatas kepada stockholders dan bondholders, yang secara langsung memberikan kontribusinya bagi perusahaan, sedangkan pihak lain sering diabaikan. Berbagai

- Dosen Fakultas Ekonomi UII

Alumni Fakultas Ekonomi UII 
kritik múncul bagi konsep akuntansi konvensional, karena akuntansi konvensional dianggap tidak dapat mengakomodasi kepentingan masyarakat secara luas. Hal ini mendorong munculnya konsep akuntansi yang baru, yang disebut sebagai Corporate Social Responsibility atau tanggung jawab social perusahaan.

Masyarakat semakin kritis dan mampu melakukan kontrol sosial terhadap dunia usaha. Perubahan pada tingkat kesadaran masyarakat tersebut memunculkan kesadararan baru tentang pentingnya melaksanakan Corporate Social Responsibility (CSR) (Daniri, 2007). Menurut Utama (2007) perkembangan CSR terkait dengan semakin parahnya kerusakan lingkungan yang terjadi di Indonesia maupun dunia, mulai dari penggundülan hutan, polusi udara dan air, hingga perubahan iklim. Sejalan dengan perkembangan tersebut, Undang-Undang No. 40 tahun 2007 tentang Perseroan Terbatas mewajibkan perseroan yang bidang usahanya di bidang atau terkait dengan bidang sumber daya alam untuk melaksanakan tanggung jawab sosial dan lingkungan.

Tuntutan - terhadap perusahaan untuk memberikan informasi yang transparan, organisasi yang akuntabel serta tata kelola perusahaan yang semakin bagus (good corporate governance) semakin memaksa perusahaan untuk memberikan informasi mengenai aktivitas sosialnya. Masyarakat membutuhkan informasi mengenai sejauh mana perusahaan sudah melaksanakan aktivitas sosialnya sehingga hak masyarakat untuk hidup aman dan tentram, kesejahteraan karyawan, dan keamanan mengkonsumsi makanan dapat terpenuhi.

Dari hasil studi literatur yang dilakukan oleh Finch (dalam Rawi, 2008) menunjukkan bahwa motivasi perusahaan untuk melakukan pengungkapan sosial lebih banyak dipengaruhi oleh usaha untuk mengkomunikasikan kepada stakeholder mengenai kinerja manajemen dalam mencapai manfaat bagi perusahaan dalam jangka panjang.

Beberapa penelitian yang terkait dengan pengungkapan tanggung jawab sosial perusahaan baik didalam maupun diluar negeri telah banyak dilakukan, diantaranya oleh Hackston dan Milne (1996), Belakaoi dan Karpik (1989), Sembiring (2005), Herman (2009) dan. Rawi (2010) yang meneliti pengaruh karakteristik perusahaan terhadap pengungkapan tanggung jawab sosial.

Fama dan Jensen (dalam Rawi, 2010) menyatakan bahwa kepemilikan manajemen yang tinggi cenderung untuk melakukan program CSR dengan mudah. Tetapi hasil penelitian Waryanto (2010) tidak menemukan adanya pengaruh kepemilikan manajemen terhadap tanggung jawab social perusahaan. Scott (dalam Fahrizqi, 2010) menyampaikan pendapat bahwa semakin tinggi leverage sebuah perusahaani, kemungkinan besar perusahaan tersebut akan mengalami pelanggaran terhadap kontrak utang, maka manajer akan berusaha untuk melaporkan laba sekarang lebih tinggi dibandingkan laba masa depan. Jadi perusahaan yang memiliki rasio leverage tinggi akan lebih sedikit 
mengungkapkan. tanggung jawab sosial perusahaan. Hal ini sejalan dengan hasil penelitian Belkaoui (dalam Anggraeni, 2006) bahwa ada hubungan negatif antara pengungkapan sosial dengan tingkat financial leverage. Sembiring (2005) dan Herman (2009) menemukan adanya pengaruh ukuran perusahaan terhadap pengungkapan tanggung jawab sosial. Nảmun Anggraeni (2006) tidak menemukan adanya pengaruh ukuran perusahaan terhadap pengungkapan tanggung jawab social. Hackston \& Milne (1996) menyajikan bukti empiris mengenai praktik pengungkapan lingkungan dan sosial pada perusahaan-perusahaan di New Zealand serta menguji beberapa hubungan potensial antara karakteristik perusahaan dengan pengungkapan sosial dan lingkungan. Hasil penelitian menunjukkan adanya konsistensi penelitiannya dengan penelitian yang sudah dilakukan di negara lain. Ukuran perusahaan berhubungan dengan jumlah pengungkapan lingkungan dan sosial sedangkan profitabilitas tidak. Penelitian yang dilakukan oleh Bowman dan Haire (1976) serta Preston (1978) mendukung. hubungan profitabilitas dengan pengungkapan tanggung jawab-sosial, sedangkan penelitian yang dilakukan Belkaoui dan Karpik (1989) membuktikan bahwa profitabilitas tidak berpengaruh terhadap pengungkapan tanggung jawab sosial perusahaan. Demikian juga penelitian yang dilakukan oleh Hackston \& Milne (1996), membuktikan bahwa profitabilitas tidak berpengaruh terhadap tanggung jawab social perusahaan.

Adanya ketidakkonsitenan hasil penelitian-penelitian terdahulu, maka perlu diteliti kembali pengaruh karakteristik perusahaan terhadap pengungkapan tanggung jawab sosial perusahaan. Penelitian ini melanjutkan penelitian yang dilakukan oleh Hardinan (2007) dan Darwis (2009). Perbedaannya, penelitian ini menambahkan variabel kepemilikan manajemen yang mengacu pada penelitian Rawi (2008).

Penelitian ini bertujuan untuk menganalisis pengaruh kepemilikan manajemen, leverage, ukuran perusahaan dan profitabilitas terhadap pengungkapan tanggung jawab sosial perusahaan.

\section{Landasan Teori dan Pengembangan Hipotesis}

\section{Pengungkapan Tanggung Jawab Sosial Perusahaan}

Pengungkapan tanggung jawab sosial perusahaan yang sering juga disebut sebagai social disclosure, corporate social reporting, social accounting (Mathews,1995) atau corporate social responsibility (Hackston dan Milne, 1996) merupakan proses pengkomunikasian dampak sosial dan lingkungan dari kegiatan ekonomi organisasi terhadap kelompok khusus yang berkepentingan dan terhadap masyarakat secara keseluruhan (Sembiring, 2005). 
Menurut Komisi Eropa dalam Susiloadi (2008) mendefinisikan CSR sebagai essentially a concept whereby companies decide voluntary to contribute to better society and a cleaner environment. Definisi ini menekankan bahwa CSR adalah suatu konsep yang menunjukkan bagaimana perusahaan secara sukarela memberikan kontribusi bagi terbentuknya masyarakat yang lebih baik dan lingkungan 'yang lebih bersih.'Sedangkan Marlia' (dalam Susiloadi, 2008) mendefinisikan CSR sebagai kepedulian perusahaan yang menyisihkan sebagian keuntungannya (profit) bagi kepentingan pembangunan manusia (people) dan lingkungan (planet) secara berkelanjutan berdasarkan prosedur (procedure) yang tepat dan profesional.

\section{Kepemilikan Manajemen}

Secara khusus kepemilikan manajer terhadap perusahaan atau yang biasa dikenal dengan istilah Insider Ownership ini didefinisikan sebagai persentase suara yang berkaitan dengan. saham dan option yang dimiliki oleh manajer dan direksi . suatu perusahaan (Mathiesen, 2004). Ada sebagian perusahaan yang mengambil kebijakan kompensasi perusahaan bagi para manajernya dengan cara memberikan hak kepada para manajer untuk memiliki sebagian saham perusahaan, Ratnaningsih dan Hartono (dalam Rawi, 2008).

Kepemilikan manajer tersebut dapat menyebabkan munculnya benefit maupun cost bagi perusahaan, karena kepemilikan manajemen tersebut akan memberikan dampak pada perilaku pihak manajemen, Jensen (dalam Rawi, 2008).

\section{Leverage}

Menurut Van Horn (1997) Financial Leverage.merupakan penggunaan sumber dana yang memiliki beban tetap, dengan harapan akan memberikan tambahan keuntungan yang lebih besar dari pada beban tetapnya, sehingga keuntungan pemegang saham bertambah. leverage digunakan untuk menggambarkan kemampuan perusahaan untuk menggunakan aktiva atau dana yang mempunyai beban tetap (fixed cost assets or funds) untuk memperbesar tingkat penghasilan (return) bagi pemilik perusahaan. Semakin tinggi tingkat Leverage akan semakin tinggi tingkat resiko yang di hadapi serta semakin besar tingkat return atau penghasilan yang diharapkan. Dengan memperbesar tingkat Leverage maka hal ini akan berarti bahwa tingkat ketidakpastian (Uncertainty) dari return yang akan diperoleh akan semakin tinggi pula, tetapi pada saat yang sama hal tersebut juga akan memperbesar jumlah return yang akan diperoleh.

\section{Size (Ukuran perusahaan)}

Size (ukuran perusahaan) mengukur besar kecilnya perusahaan. Bisa diukur berdasarkan jumlah aktiva (aktiva tetap, tidak berwujud dil), jumlah tenaga 
Erna Hidayah \& Windi Pamungkas, Analisis Pengaruh Karakteristik Perusahaan.....

kerja, volume penjualan dan kapitalisasi pasar, Cahyonowati (dalam Sulastini, 2007).

Ukuran perusahaan dari segi total aktiva dilihat dari segi total aktiva yang dimiliki oleh perusahaan tersebut karena perusahaan besar memiliki sumber daya yang besar sehingga perusahaan perlu dan mampu untuk membiayai penyediaan informasi untuk keperluan internal maupun eksterna!.

\section{Profitabilitas}

Profitabilitas merupakan kemampuan perusahaan untuk menghasilkan laba untuk - meningkatkan nilai pemegang saham. Terdapat beberapa ukuran untuk menentukan profitabilitas perusahaan, yaitu : return on equity (ROE), return on assets (ROA), earning per share (EPS), net profit dan operating ratio. (Sulastini, 2007). ROA berguna mengukur efektifitas penggunaan asset. Sedang ROE mengukur efisiensi pemegang. saham mempertaruhkan penggunaan sahamnya didalam bisnis perusahaan.

\section{Pengembangan Hipotesis}

\section{Pengaruh Kepemilikan Manajemen terhadap Pengungkapan Tanggung} Jawab Sosial Perusahaan

Kepemilikan manajerial merupakan bonding mechanism yang digunakan untuk mengurangi konflik keagenan antara manajemen dengan pemegang saham (Megginson, 1997: 375). Kekayaan pribadi manajemen yang terkait dengan nilai perusahan diharapkan akan membuat manajemen untuk bertindak demi meningkatkan nilai perusahaan dengan sendirinya.

Semakin besar kepemilikan manajemen dalam suatu perusahaan maka semakin besar juga perusahaan tersebut melakukan pengungkapan sosial karena kepemilikan manajemen memperoleh keuntungan khusus atas biaya pengungkapan sosial dari pemegang saham lainnya, maka demi meningkatkan nilai perusahaan, pihak manajemen melakukan pengungkapan tanggung jawab socialnya.

Fama dan Jensen (dalam Rawi, 2010) menyimpulkan bahwa semakin tinggi tingkat kepemilikan manajemen, semakin tinggi pula program CSR. Morck, Shleifer dan Vishny. (1988) menyatakan bahwa kepemilikan manajemen berpengaruh positif terhadap pengeluaran program CSR dengan tujuan meningkatkan nilai perusahaan, tetapi pada suatu titik yang akan mengurangi nilai perusahaan, ditemukan hubungan negatif. Oleh karena itu dirumuskán hipotesis sebagai berikut:

H1 : Kepemilikan manajemen berpengaruh positif terhadap pengungkapan tanggung jawab sosial perusahaan. 


\section{Pengaruh Leverage terhadap Pengungkapan Tanggung Jawab Sosial Perusahaan}

Leverage digunakan untuk menggambarkan kemampuan perusahaan untuk menggunakan aktiva atau dana yang mempuriyai beban tetap (fixed cost assets or funds) untuk "memperbesar tingkat penghasilan (return) bagi pemilik perusahaan. Belkaoui dan Karpik (1989) menyatakan bahwa semakin tinggi tingkat rasio leverage, semakin besar kemungkinan perusahaan akan. melanggar perjanjian kredit sehingga perusahaan akan berusaha untuk melaporkan laba sekarang lebih tinggi. Agar laba yang dilaporkan tinggi, maka manajer harus mengurangi biayabiaya termasuk biaya untuk mengungkapkan informasi sosial. Biaya pengungkapan tanggung jawab sosial yang terbatas, maka pengungkapan informasi sosial menjadi renidah atau terbatas. Berdasarkan penelitian terdahulu dan teori agensi, maka perusahaan dengan tingkat leverage yang tinggi akan mengurangi pengungkapan tanggung jawab sosial yang dibuatnya agar tidak menjadi sorotan dari para debtholders. Dengan demikian leverage diprediksikan berpengaruh negatif terhadap pengungkapan tanggung jawab sosial perusahaan. Sembiring (2003) menyatakan bahwa leverage berpengaruh negatif signifikan terhadap pengungkapan tanggung jawab sosial perusahaanHipotesis yang diujikan sebagai berikut:

H2 : Leverage berpengaruh negatif terhadap pengungkapan tanggung jawab sosial perusahaan.

\section{Pengaruh Size terhadap Pengungkapan Tanggung Jawab Sosial Perusahaan}

Menurut Agency Theory, perusahaan yang besar cenderung mempunyai biaya keagenan yang lebih besar dibandingkan perusahaan kecil. Untuk mengurangi biaya keagenan tersebut, maka perusahaan besar cenderung mengungkapkan informasi yang lebih luas dibandingkan dengan perusahaan kecil. Disamping itu, perusahaan besar merupakan emiten yang banyak disoroti, pengungkapan yang lebih besar merupakan pengurangan biaya politis sebagai wujud tanggung jawab sosial perusahaan (Sembiring, 2005). Sehingga bisa dirumuskan hipotesis sebagai berikut ini.

$\mathrm{H} 3$ : Size (ukuran perusahaan) berpengaruh positif terhadap pengungkapan tanggung jawab sosial perusahaan.

\section{Pengaruh Profitabilitas terhadap Pengungkapan Tanggung Jawab Sosial Perusahaan}

Semakin besar tingkat profitabilitas perusahaan maka semakin besar juga perusahaan tersebut melakukan pengungkapan social. Hal ini dikarenakan adanya persepsi bahwa pengungkapan tanggung jawab sosial bukanlah aktivitas yang 
merugikan dan tidak bermanfaat bagi keberlangsungan perusahaan tetapi aktivitas 'ini merupakan langkah strategis jangka panjang yang akan memberikan efek positif bagi perusahaan.

Hubungan antara pengungkapan tanggung jawab sosial perusahaan dan profitabilitas perusahaan telah diyakini mencerminkan pandangan bahwa reaksi sosial memerlukan gaya manajerial yang sama dengan gaya manajerial yang dilakukan pihak manajemen untuk membuat suatu perusahaan memperoleh ' keuntungan, Bowman dan Haire (dalam Sembiring, 2005).

Hackston \& Milne (dalam Anggraini, 2006) menyatakan bahwa semakin tinggi tingkat profitabilitas perusahaan maka semakin besar pengungkapan informasi socialnya.

Sehingga hipotesis penelitiannya adalah sebagai berikut:

H4 : Profitabilitas berpengaruh positif terhadap pengungkapan tanggung jawab sosial perusahaan.

\section{Metode Penelitian}

\section{SampeI}

Sampel dalam penelitian ini adalah perusahaan manufaktur yang terdaftar di Bursa Efek Indonesia pada periode tahun 2009-2010 yang memenuhi kriteria aktif memperdagangkan sahamnya, menerbitkan laporan tahunan, dan mengungkapkan tanggung jawab sosialnya.

\section{Definisi operasional dan pengukuran variabel}

\section{Pengungkapan Tanggung Jawab Sosial}

Pengungkapan mengenai pertanggungjawaban sosial perusahaan mencerminkan suatu pendekatan perusahaan dalam melakukan adaptasi dengan lingkungan yang dinamis dan bersifat multidimensi. Pengungkapan tanggung jawab sosial perusahaan adalah mekanisme bagi suatu organisasi untuk secara sukarela mengintegrasikan perhatian terhadap lingkungan dan sosial ke dalam operasinya dan interaksinya dengan stakeholders yang melebihi tanggung jawab organisasi di bidang hukum, Darwin (dalam Rawi, 2008).

Variabel pengungkapan tanggung jawab sosial perusahaan diukur dengan indeks pengungkapan tanggung jawab sosial (CSRI). Instrumen pengukuran yang digunakan adalah item-item pengungkapan tanggung jawab sosial yang berjumlah 78 item yang terdiri dari 7 kategori yaitu lingkungan, energi, kesehatan d dan - keselamatan "tenaga kerja, lain-lain tenaga kerja, produk, 
keterlibatan masyarakat dan umum seperti yang digunakan oleh Hackston dan Milne (dalam Sembiring, 2005).

Indeks dihitung dengan cara mengecek pengungkapan setiap item dalam laporan tahunan perusahaan. Apabila item pengungkapan tersebut ada dalam laporan tahunan perusahaan maka diberi skor 1 dan jika item pengungkapan tersebut tidak ada dalam laporan tahunan perusahaan maka diberi skor 0 . Berikut adalah formula untuk menghitung indeks pengungkapan tanggung jawab sosial perusahaan, (Haniffa et al, 2005).

$$
\operatorname{CsRI} \frac{\sum X_{i j}}{N_{j}}
$$

Keterangan:

CSRI $\mathrm{j}$ : Indeks Pengungkapan Tanggung Jawab Sosial perusahaan $\mathrm{j}$,

$\mathrm{Nj} \quad$ : jumlah item untuk perusahaan j.Nj 78.

$\mathrm{Xij} \quad$ : dummy variable: $1=\mathrm{jika}$ item $\mathrm{i}$ diungkapkan; $0=\mathrm{jika}$ item I tidak diungkapkan.

Dengan demikian, $0 \leq \mathrm{CSRI} \mathrm{j} \leq 1$.

\section{Kepemilikan Manajemen}

Kepemilikan manajemen adalah prosentase suara yang berkaitan dengan saham dan option yang dimiliki oleh manajer dan direksi suatu perusahaan Mathiesen (dalam Rawi, 2008). Dalam penelitian ini, kepemilikan manajemen diukur menggunakan prosentase saham yang dimiliki oleh pihak manajemen (direksi).

\section{Leverage}

Tingkat Leverage menunjukkan seberapa besar asset perusahaan diperoleh atau didanai oleh utang. Variabel ini diukur dengan membagi total utang dengan . total asset Jensen et al (dalam Rawi, 2008). Secara matematis rasio total utang. terhadap total asset dihitung menggunakan rumus sebagai berikut:

$$
\text { Dejtit } \frac{\text { TDit }}{\text { Total Aset it }}
$$

\section{Keterangan:}

TDit = Jumlah Total Utang perusahaan i pàda periode $t$

Total Assetit $=$ Total Aset yang dimiliki perusahaan i pada periode $t$ 


\section{Size (Ukuran perusahaan)}

Size.(ukuran perusahaan) bisa didasarkan pada jumlah aktiva (aktịva tetap, tidak berwujud dan lain-lain), jumlah tenaga kerja, volume penjualan dan kapitalisasi pasar Nur Cahyonowati (dalam Sulastini, 2007). Novita dan Djakman (2008) menggunakan proksi log assets. Hossain dkk
(2006) menggunakan total assets value untuk mengukur size perusahaan. Dalam penelitian ini size diukur menggunakan total asset yang dilogaritmakan karena total asset berbentuk nominal.

$$
\text { Size }=\log \text { Total Asset }
$$

\section{Profitabilitas}

Profitabilitas merupakan kemampuan perusahaan untuk menghasilkan laba untuk meningkatkan nilai pemegang saham. Profitabilitas dalam penelitian ini menggunakan proksi Return on Equity (ROE) seperti Hakston dan Milne (1996). ROE mengukur efisiensi perusahaan dälam menggunakan kapital dari para pemilik. ROE dihitung dengan rumus sebagai berikut:

$$
\text { Return On Equity }(R O E)=\frac{\text { Net Income }}{\text { Shareholder's. Equity }}
$$

Keterangan;

Net Income : Laba bersih

Shareholder's Equity : Total Ekuitas

\section{Teknik Analitis}

Dalam penelitian ini digunakan analisis regresi linear berganda dengan ;rumus sebagai berikut;

$$
\mathrm{CSR}=\mathrm{b}_{0}+\mathrm{b}_{1} \mathrm{MAN}+\mathrm{b}_{2} \mathrm{LEV}+\mathrm{b}_{3} \mathrm{SIZE}+\mathrm{b}_{4} \mathrm{ROE}+\mathrm{e}
$$

Keterangan;

CSR : Pengungkapan Tanggung Jawab Sosial Perusahaan $b_{0}$ : konstanta

MAN : Kepemilikan Manajemen

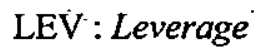

SIZE : Size (Ukuran perusahaan)

ROE : Profitabilitas

$\mathrm{b}_{1}, \mathrm{~b}_{2}, \mathrm{~b}_{3}, \mathrm{~b}_{4}$ : Koofisien regresi $:=$

e : error 


\section{Hasil dan Pembahasan}

Jumlah sampel yang terpilih dalam . penelitian ' ini sebanyak 48 perusahaan manufaktur. Variabel dependen yaitu pengungkapan tanggung jawab sosial perusahaan (CSR) diperoleh nịlai minimum sebesar 5\% dan maksimun $49 \%$ dengan rata-rata 21\%. Variabel independen yaitu kepemilikan manajemen (MAN) diperoleh nilai minimum $0.0001 \%$, maksimum $70 \%$ dengan rata-rata $3.4871 \%$. Variabel leverage (LEV) nilai minimum sebesar $4 \%$, maksimum $87 \%$ dengan ratarata $45 \%$. Variabel ukuran perusahaan (SIZE) yaitu diukur menggunakan total asset yang dimiliki oleh perusahaan. Total asset perusahaan berbentuk nominal yaitu dengan angka miliaran maka diformulasikan dalam bentuk logaritma (Log). Nilai minimum untuk ukuran perusahaan sebesar 10.89, nilai maksimum 13.67 dan nilai rata-rata nya 12.1900 . Variabel profitabilitas (ROE), nilai minimumnya $16.03 \%$, maksimum $83.70 \%$ dengan rata-rata $15 \%$. Profitabilitas bernilai negatif berarti perusahaan tersebut mengalami kerugian.

\section{Uji Asumsi Klasik}

\section{Uji Normalitas}

Uji normalitas bertujuan untuk menguji apakah dalam sebuah model regresi, variabel dependen, variabel independen, atau keduanya mempunyai distribusi normal atau tidak. Untuk menguji normal data ini menggunakan metode analisis grafik dan melihat.normal probability plot. Hasil untuk uji normalitas adalah sebagai berikut :

\section{Gambar 1}

Uji Normalitas

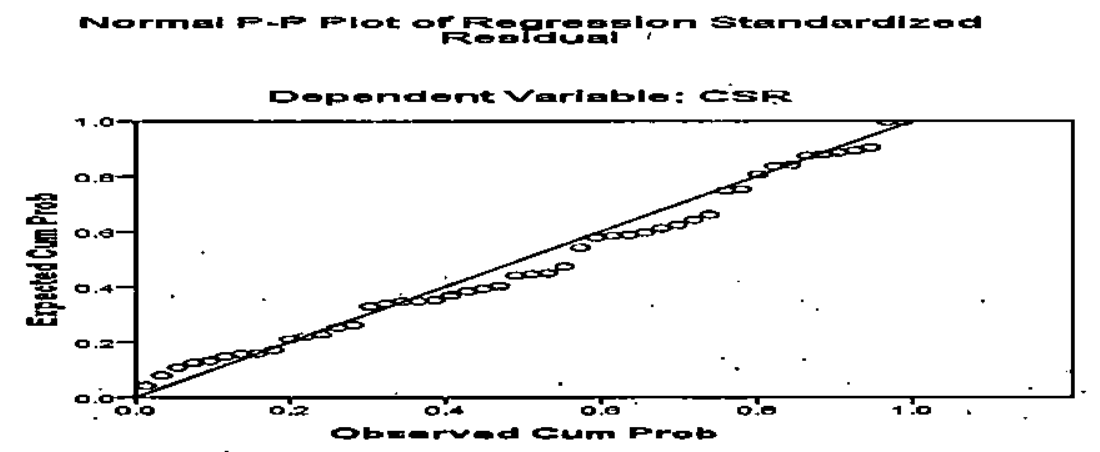

Hasil uji normalitas dengan menggunakan analisis grafik yaitu dengan menggunakan grafik normal p-plot. menunjukkan bahwa grafik 
memberikan pola distribusi normal, dan pada grafik terlihat titik-titik menyebar di sekitar garis diagonal serta penyebarannya mengikuti arah garis diagonal.

\section{Uji Heteroskedastisitas}

Uji heteroskedastisitas bertujuan menguji apakah dalam model regresi terjadi ketidaksamaan variance dari residual satu pengamatan ke pengamatan yang lain (Ghozali, 2005). Heteroskedastisitas diukur dengan metode plot, sbb:

\section{Gambar 2}

\section{Uji Heteroskedastisitas}

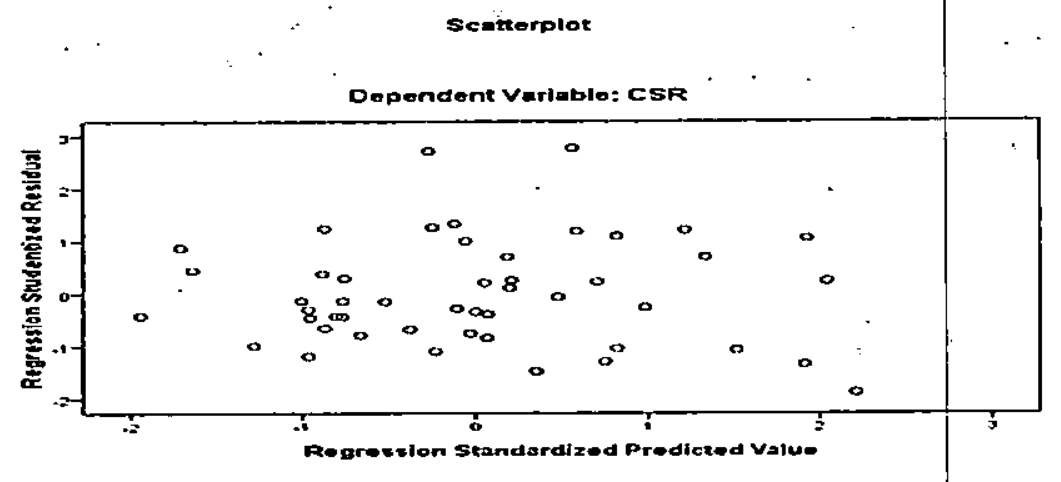

Berdasarkan hasil pengujian dengan tingkat probabilitas signifikansi variabel independen $<0.05(5 \%)$, pada gambar 4.5 dapat dilihat bahwa tidak ada 'pola yang jelas atau menyebar, titik-titik penyebaran berada berada diatas dan dibawah angka 0 pada sumbu $X$. Dari gambar tersebut dapat disimpulkan bahwa tidak terjadi heteroskedastisitas.

\section{Uji Multikolinearitas}

Uji multikolinearitas bertujuan untuk menguji apakah model regresi ditemukan adanya korelasi antar variabel bebas atau independen (Ghozali, 2005). Multikolinearitas dilihat dari nilai toleran dan" Variance Inflation Factor atau VIF. Nilai cut-off yang umum dipakai adalah nilai toleran 0.10 àtau sama dengan nilai VIF diatas 10 sehingga data yang tidak terkena mulkolinearitas nilai toleransinya harus lebih dari 0.10 atau VIF kurang dari 10. Berikut tabel hasil uji multikolinearitas. 
Tabel 1

Uji Multikolinearitas

Coefficients $^{\mathrm{a}}$

\begin{tabular}{|ll|l|l|}
\hline \multirow{2}{*}{ Model } & \multicolumn{2}{|l|}{ Collinearity Statistics } \\
\cline { 2 - 4 } & Tolerance & VIF \\
\hline $1 \quad$ MAN & .937 & 1.067 \\
LEV & .856 & 1.168 \\
SIZE & .753 & 1.328 \\
ROE & .831 & 1.204 \\
\hline
\end{tabular}

a. Dependent Variable: CSR

Hasil pengujian tolerance menunjukan tidak ada variabel bebas yang memiliki nilai tolerance kurang dari 0.10 (10\%). Hasil perhitungan VIF juga menunjukan bahwa tidak ada satu variabel bebas yang memiliki nilai VIF lebih dari 10. Oleh karena itu dapat disimpulkan bahwa tidak ada multikolinearitas antara variabel independen dalam model regresi.

\section{Uji Autokorelasi}

Untuk mengetahui ada tidaknya autokorelasi dalam model regresi maka digunakan uji Durbin Watson (D-W). Hasil uji D-W tersebut adalah sebagai berikut;

Tabel 2

Uji Autokorelasi

Model Summary ${ }^{b}$

\begin{tabular}{|l|l|l|l|l|l|}
\hline Model & $R$ & $R$ Square & $\begin{array}{l}\text { Adjusted R } \\
\text { Square }\end{array}$ & $\begin{array}{l}\text { Std. Error of } \\
\text { the Estimate }\end{array}$ & Durbin-Watson \\
\hline $\mathrm{I}$ & $.550^{\mathrm{a}}$ & .303 & .238 & .09042 & 2.144 \\
\hline
\end{tabular}

a. Predictors: (Constant), ROE, LEV, MAN, SIZE

b. Dependent Variable: CSR

\begin{tabular}{|c|c|c|c|}
\hline $\mathrm{D}-\mathrm{W}$ & $\mathrm{dU}$ & 4-dU & Keterangan \\
\hline 2.144 & 1.721 & 2.279 & Bebas autokorelasi \\
\hline
\end{tabular}

Berdasarkan hasil olah data statistik diperoleh nilai $\mathrm{D}-\mathrm{W}$ - sebesar 2.144. Sedangkan. nilaị dU diperoleh nilai sebesar $1.721(K=4, N=50$, peneliti 
'mengambil $\mathrm{N}=50$ karena pada tabel $\mathrm{D}-\mathrm{W}$ tidak terdapat $\mathrm{N}=48$ ); maka diketahui bahwa nilai $\mathrm{D}-\mathrm{W}$ berada diantara nilai $\mathrm{dU}$ dan $(4-\mathrm{dU}) \cdot$. Dengan demikian menunjukkan bahwa model regresi tersebut bebas dari masalah autokorelasi.

\section{Uji Hipotesis}

Pengujian regresi parsial dilakukan dengan menggunakan significance level $0,05(\alpha=5 \%)$. Hasil regresi parsial tersebut dapat dilihat pada tabel berikut ini:

Tabel 3

Uji Regresi Parsial (Uji t)

Coefficients $^{\mathrm{a}}$

\begin{tabular}{|ll|l|l|l|l|l|}
\hline \multirow{2}{*}{} & \multicolumn{2}{|c|}{$\begin{array}{c}\text { Unstandardized } \\
\text { Coefficients }\end{array}$} & $\begin{array}{l}\text { Standardized } \\
\text { Coefficients }\end{array}$ & & \\
\cline { 2 - 7 } & Model & $\mathrm{B}$ & Std. Error & Beta & $\mathrm{t}$ & Sig. \\
\hline 1 & (Constant) & .623 & .267 & & 2.332 & .024 \\
& MAN & -.0010 & .001 & -.099 & -.756 & .454 \\
& LEV & -.002 & .001 & -.306 & -2.227 & .031 \\
SIZE & .073 & .023 & .471 & 3.210 & .003 \\
ROE & .001 & .001 & .164 & 1.177 & .246 \\
\hline
\end{tabular}

a. Dependent Variable: CSR

Dari uji regresi parsial (uji t) tersebut dapat diperoleh p-value dari masingmasing variabel independen sehingga dapat menguji hipotesis yang telah diajukan. Penjelasan tentang uji hipotesis dapat dilihat dalam penjelasan sebagai berikut:

\section{Hipotesis 1}

Hasil olah data menunjukan nilai t sebesar -0.756 dengan p-value 0.454 . Nilai $p$-value jauh lebih tinggi dibandingkan dengan $\alpha=0.05$, sehingga hipotesis pertama gagal menolak HO. Dapat disimpulkan bahwa kepemilikan manajemen tidak berpengaruh positif terhadap pengungkapan tanggung jawab sosial. Hipotesis 2

Hasil olah data menunjukan nilai $t$ sebesar -2.227 dengan $p$-value 0.031 . Nilai $p$-value lebih rendah dibandingkan dengan $\alpha=0.05$, sehingga hipotesis.kedua berhasil menolak H0. Sehingga dapat disimpulkan bahwa leverage berpengaruh negatif terhadap pengungkapan tanggung jawab sosial perusahaan.

\section{Hipotesis 3}

Hasil olah data menunjukan nilai t sebesar 3.210 dengan $p$-value 0.003 . Nilai $p$-value jauh lebih rendah dibandingkan dengan $\alpha=0.05$, maka hipotesis 
ketiga berhasil menolak Ho. Sehingga dapat disimpulkan bahwa' size (ukuran perusahaan) berpengaruh positif terhadap pengungkapan tanggung jawab sosial.

\section{Hipotesis 4}

Hasil olah data menunjukan nilai $t$ sebesar 1.177 dengan $p$-value 0.246 . Nilai $p$-value jauh lebih tinggi dibandingkan dengan $\alpha=0.05$; maka hipotesis keempat gagal menolak H0. Sehingga dapat disimpulkan bahwa profitabilitas tidak berpengaruh positif terhadap pengungkapan tanggung jawab sosial perusahaan.

\section{Pembahasan}

Perusahaan yang melakukan pengungkapan tanggung jawab sosial dengan nilai tertinggi adalah PT. Kimia Farma Tbk yaitu sekitar 38 item, sedang perusahaan yang melakukan pengungkapan tanggung jawab sosial terendah adalah PT. Inti Keramik Alam Industri tbk dan PT. Pelangi Indah Canindo tbk yaitu hanya 4 item dari total 78 item yang diharapkan. Dari penjelasan tersebut dapat dikatakan bahwa untuk pengungkapan tanggung jawab sosial penusahaan manufaktur di Indonesia relatif masih rendah. Hal ini mungkin disebabkan oleh belum adanya standar baku yang mengatur mengenai bagaimana perusahaan harus melakukan pengungkapan tanggung jawab sosial, dan item-item sosial apa yang harus diungkapkan.

Hasil uji hipotesis pertama (H1) menunjukkan bahwa kepemilikan manajemen tidak berpengaruh positif terhadap pengungkapan tanggung jawab sosial perusahaan. . Hal tersebut kemungkinan disebabkan oleh kepemilikan saham yang dimiliki oleh pihak manajemen perusahaan manufaktur di Indonesia relatif kecil yaitu dengan rata-rata kepemilikan sebesar $3.4871 \%$. Hasil penelitian ini konsisten dengan hasil penelitian sebelumnya yang dilakukan oleh Barnea dan Rubin (2006), Huafang dan Jianguo (2007), Said et.al (2009), dan Waryanto (2010) yang membuktikan bahwa kepemilikan manajemen tidak mempengaruhi pengungkapan tanggung jawab social. Tetapi hasil penelitian ini tidak sesuai dengan hasil penelitian yang dilakukan oleh Anggraeni (2006), Rosmasita (2007) dan Rawi (2008) yang membuktikan bahwa kepemilikan manajemen berpengaruh terhadap pengungkapan tanggung jawab sosial.

Hasil uji hipotesis 2 membuktikan bahwa leverage berpengaruh signifikan terhadap pengungkapan tanggung jawab sosial perusahaan. Hasil ini sesuai dengan teori agensi yang menyatakan bahwa manajemen perusahaan dengan tingkat leverage yang tinggi akan mengurangi pengungkapan tanggung jawab sosial yang dibuatnya agar tidak menjadi sorotan dari para debtholder (Sembiring, 2005). Hasil-- penelitian -- ini---sesuai-dengan penelitian sebelumnya yang - dilakukan oleh Belkaoli dan Karpik (1989), Robert (1992) dan Cormier dan Magnan (1999) yang menemukan pengaruh leverage terhadap pengungkapan tanggung jawab sosial yang dilakukan oleh perusahaan, tetapi hasil penelitian ini 
tidak sesuai dengan hasil penelitian yang dilakukan oleh Hackston dan Milne (1996), Anggraeni (2006), Rawi (2008) dan Herman (2009) yang tidak menemukan adanya pengaruh leverage terhadap pengungkapan tanggung jawab sosial perusahaan:

Hasil uji hipotesis 3 berhasil membuktikan bahwa size (ukuran perusahaan) berpengaruh positif terhadap pengungkapan tanggung jawab sosial perusahaan. Hasil dalam penelitian ini mendukung penelitian yang dilakukan oleh Belkaoui dan Karpik (1989), Adam et. al., (1995, 1998), Hackston dan Milne (1996), Sembiring (2005) dan Herman (2009), tetapi hasil penelitian ini tidak sesuai dengan penelitian yang dilakukan oleh Anggraeni (2006) dan Nurkhin (2007) yang tidak menemukan adanya pengaruh size (ukuran perusahaan) terhadap pengungkapan tanggung jawab sosial perusahaan.

Hasil uji hipotesis 4 membuktikan bahwa profitabilitas tidak berpengaruh positif terhadap pengungkapan tanggung jawab sosial perusahaan. Artinya adalah seberapa besar profit yang dihasilkan oleh perusahaan tidak akan mempengaruhi besar kecil nya pengungkapan tanggung jawab sosial perusahaan. Hal ini mungkin disebabkan karena pengungkapan tanggung jawab sosial perusahaan sifatnya masih sukarela, sehingga perusahaan beranggapan bahwa konsumen dalam menggunakan produk tidak melihat pengungkapan tanggung jawab sosial perusahaan tersebut, sehingga tidak berpengaruh terhadap laba yang diperoleh perusahaan. Hasil penelitian ini konsisten dengan penelitian yang dilakukan oleh Hackston dan Milne (1996), Sembiring (2005), Anggraeni (2006) dan Herman (2009, tetapi tidak sesuai dengan penelitian yang dilakukan oleh Hopkins (2004), Baron (2005) dan Nurkhin (2007) yang membuktikan bahwa profitabilitas berpengaruh| terhadap pengungkapan tanggung jawab sosial.

\section{Kesimpulan dan Implikasi}

\section{Kesimpulan}

Penelitian ini berhasil membuktikan bahwa kepemilikan manajemen berpengaruh positif terhadap pengungkapan tanggungjawab social perusahaan, dan leverage berpengaruh negatif terhadap pengungkapan tanggungjawab social perusahaan. Tetapi penelitian ini gagal membuktikan bahwa size (ukuran penusahaan) dan . profitabilitas berpengaruh positif terhadap. pengungkapan. tanggungjawab social perusahaan.

\section{Keterbatasan Penelitian dan Saran.}

a. Periode pengamatan yang relatif pendek. Disarankan untuk peneliti berikutnya menambah periode pengamatan, agar bisa mendapatkan gambaran yang lebih baik. 
b. Adanya unsur subjektifitas dalam penentuan dan pengukuran indeks pengungkapan tanggung jawab social, karena belum adanya standar baku. Untuk peneliti berikutnya, sebaiknya menggunakan indikator yang berbeda dengan penelitian ini, misalnya:-menurut GRI (Global Reporting Initiatives).

c. variabel independen relatif sedikit. Untuk peneliti selanjutnya dapat menambah variable lain, seperti kepemilikan institusional, ukuran dewan komisaris, tipe industri dan umur perusahaan. 


\section{DAFTAR PUSTAKA}

Ahmad Nurkhin, Corporate Governance Dan Profitabilitas; Pengaruhnya Terhadap Pengungkapan Tanggung Jawab Sosial Perusahaan (Studi Empiris Pada Perusahaan Yang Tercatat Di Bursa Efek Indonesia) , 2007. Anggraeni, Fr. Reni-Retno, "Pengungkapan informasi sosial dan faktor-faktor yang mempengaruhi pengungkapan informasi sosial dalam laporan keuangan tahunan (studi empiris pada perusahaan-perusahaan yang terdaftar Bursa Efek Jakarta), Makalah disampaikan pada Simposium Nasional Akuntansi IX, 23-26 Agustus, Padang, 2006.

Anggara Fahrizqi, Faktor-Faktor yang Mempengaruhi Pengungkapan Corporate Social Responsibility (CSR) dalam Laporan Tahunan Perusahaan (Studi. Empiris pada Perusahaan Manufaktur yang terdaftar dalam Bursa Efek Indonesia), Skripsi S-1, Fakultas Ekonomi, Universitas Diponegoro, Semarang, 2010.

Baron,D. Corporate Social Responsibility and Social Enterpreunership. Research paper No.1916, Stanford Graduate School of Business. 2005.

Belkaoui, Ahmed and Philip G. Karpik, Determinants of the Corporate Decision to Disclose Sosial Information. Accounting, Auditing and Accountabilit Journal. Vol. 2, No. 1, p. 36-51, 1989.

Darwin, Ali. Penerapan Sustainability Reporting di Indonesia. Konvensi Nasional Akuntansi V, Program Profesi Lanjutan. Yogyakarta, 13-15 Desember, 2004.

Darwin, Ali. CSR, Standards \& Reporting. Seminar Nasional Universitas Katolik Soegijapranata, 2008.

Finch, Nigel. The Motivations for Adopting Sustainability Disclosure. Macquaarie Graduate School of Management.Social Science Research Network. 2005.

Gray, Rob; Colin Dey; Dave Owen; Richard Evans and Simon Zadek. Struggling with the praxis of social Accounting:Stakeholders, Accountability, Audits and Procedures. Accounting, Auditing and Accountability Journal.Vol.10, No.3,p.325-364. 1997.

Hackstone, David dan Milne, Marcus J. Some Determinants of Social and Environmental Disclosure in New Zealand Companies", Accounting, Auditing and Accountability Journal, Vol. 9, No. 1, p. 7خ-108, 1996.

Hardhina Rosmasita, Faktor-Faktor Yang Mempengaruhi Pengungkapan Sosial (Social Disclosure) Dalam Laporan Keuangan Tahunan Perusahaan Manufaktur Di Bursa Efek Jakarta, Skripsi S-1,Fakultas Ekonomi, Universitas Islam Indonesia; Yogyakarta, 2007. 
Herman Darwis, Ukuran Perusahaan ,Profitabilitas, dan Financial Leverage terhadap Pengungkapan Tanggung Jawab Sosial Pensahaan High Profile di BEI, Jurnal keuangan dan perbankan, Vol.13 No.1; hal 52-61; Januari, 2009.

Susiloadi, Priyanto, Implementasi Corporate Social Responsibility Untuk Mendukung.Pembangunan Berkelanjutan, ISSN, Vol.4 No.2, hal 123-130, 2008.

Rawi, Pengaruh Kepemilikan Manajemen, Institusi, Dan Leverage Terhadap Corporate Social Responsibility Pada Perusahaan Manufaktur Yang Listing Di Bursa Efek Indonesia, Tesis S-2, Magister Akuntansi, Universitas Diponegoro, Semarang, 2008. .

Rawi dan Munawar Muchlish, Kepemilikan Manajemen, Kepemilikan Institusi, Leverage dan Corporate Social Responsibility, Simposium Nasional Akuntansi XIII, Purwokerto, 2010.

Roshima Said, Yuserrie Hj Zainuddin, Hasnah Haron. The relationship between . corporate social responsibility disclosure and corporate govemance characteristics in Malaysian public listed companies. Social Responsibility Journal, Vol. 5 Iss: 2, pp.212-226. 2009.

Sembiring, Eddy Rismanda, Karakteristik Perusahaan dan Pengungkapan Tanggung Jawab Sosial : Study Empiris Pada Perusahaan yang Tercatat di Bursa Efek Jakarta. Seminar Nasional Akuntansi VIII, Solo, 15-16 September, 2005.

Sulastini,Sri Pengaruh Karakteristik Perusahaan Terhadap Social Disclosure Perusahaan Manufaktur Yang Telah Go Public, Skripsi S-1, Fakultas Ekonomi, Universitas Negeri Semarang, Semarang, 2007.

Waryanto, Pengaruh karakteristik Good Coorporate Goovernance (GCG) terhadap Luas Pengungkapan Corporate Social Responsibility (CSR) Di Indonesia, Skripsi-S-1, Fakultas Ekonomi, Universitas 'Diponegoro, Semarang, 2010. 